\title{
Chapter 16 \\ Forests of East Australia: \\ The 35th Biodiversity Hotspot
}

\author{
Kristen J. Williams, Andrew Ford, Dan F. Rosauer, Naamal De Silva, \\ Russell Mittermeier, Caroline Bruce, Frank W. Larsen, and Chris Margules
}

\begin{abstract}
The newly identified "Forests of East Australia" Global High Biodiversity Hotspot corresponds with two World Wildlife Fund (WWF) Ecoregions: the Eastern Australian Temperate Forests and Queensland's Tropical Rain forests. The region contains more than 1,500 endemic vascular plants, meeting the criterion for global biodiversity significance, and more than $70 \%$ of natural areas have been cleared or degraded, meeting the criterion for a hotspot. The hotspot, although covering a large latitudinal range $\left(15.5^{\circ}-35.6^{\circ}\right.$ South $)$, has a predominantly summer rainfall pattern with increasing rainfall seasonality northwards into tropical areas of north Queensland. It covers large tracts of elevated tablelands and drier inland slopes, particularly in New South Wales, where it extends inland beyond the New England Tablelands and the Great Dividing Range. Varied soils result in a mosaic pattern of vegetation. Sclerophyllous communities dominated by Australia's iconic plant, the gum-tree (Eucalyptus species), are the most prevalent vegetation type. Significant areas of rain forest exist throughout the region, much of which has persisted continuously since Gondwanan times, providing a rich living record of evolution over more than 100 million years. The human population of the hotspot as of 2006 was over nine million, with a population density of 36 people per square kilometer, mainly concentrated along the coast. About $18 \%$ of the land area is under some form of formal protection for its natural values. Gaps in the protected area network include some centers of plant endemism and some areas of critical habitat for threatened species. Whole of landscape conservation initiatives are enhancing connectivity throughout the Great Dividing Range through voluntary protection and restoration programs.
\end{abstract}

K.J. Williams $(\bowtie) \bullet$ A. Ford $\bullet$ D. F. Rosauer $\bullet$ N. De Silva $\bullet$ R. Mittermeier $\bullet$ C. Bruce $・$ F.W. Larsen $\bullet$ C. Margules

CSIRO Ecosystem Sciences - GPO Box 1700, Canberra, ACT 601, Australia

e-mail: Kristen.Williams@csiro.au 


\section{Vital Signs}

\begin{tabular}{lr}
\hline Hotspot Original Extent (sq. km.) & 253,200 \\
Hotspot Primary Vegetation Remaining (sq. km.) & 58,900 \\
Plant Species & $>8,257$ \\
Endemic Plant Species & $>2,144$ \\
Vertebrate Species & $>1,141$ \\
Endemic Vertebrate Species & $>152$ \\
Area Protected $\left(\mathrm{km}^{2}\right)$ & 46,600 \\
Area Protected within IUCN categories I-IV $\left(\mathrm{km}^{2}\right)$ & 41,300 \\
\hline
\end{tabular}

\subsection{Overview}

When the hotspots concept was first developed by Myers (1988), he included the Queensland Wet Tropics as one of his ten original hotspots, in large part because of its high plant endemism. Later, in the second major revision of the hotspots concept (Mittermeier et al. 2004), the Queensland Wet Tropics was given an "honorable mention" chapter (Stanton et al. 2004), even though it fell short of meeting the cutoff criteria for full hotspots status. Subsequently, on comparing the size of the Queensland Wet Tropics to other hotspots, and recognizing that it represented only a small portion of a much larger forested area in eastern Australia, the authors decided that further analysis was necessary to see if this larger Australian forest complex merited inclusion on the hotspots list. This analysis, led by the Australian co-authors of this chapter, determined without a doubt that the Forests of East Australia should be added to the list as the $35^{\text {th }}$ hotspot. The results of this analysis are presented here.

The newly identified Forests of East Australia Hotspot consists of a discontinuous coastal stretch along the Australian states of Queensland and New South Wales, extending inland and further west, although it does include the New England Tablelands and the Great Dividing Range. Its boundaries correspond to a combination of two World Wildlife Fund (WWF) Ecoregions: the Eastern Australian Temperate Forests and Queensland's Tropical Rain Forests (Fig. 16.1).

The hotspot, although covering a large latitudinal range $\left(15.5^{\circ}-35.6^{\circ}\right.$ South $)$, has a predominantly summer rainfall pattern with increasing rainfall seasonality northwards into the tropical areas of north Queensland. Annual rainfall is unpredictable from year to year varying on average between $550 \mathrm{~mm}$ in the more arid savanna regions to 4,500 $\mathrm{mm}$ near the tropical coast. Mountain tops in the northern "Wet Tropics" region have recorded annual rainfall events in excess of 12,000 mm. Temperatures are also variable, with annual winter snowfalls at high elevations in the south and a tropical climate in the far north. Altitudinal variation is from sea level to about $1,600 \mathrm{~m}$. The hotspot covers a broad range of environments including flat to rolling and undulating coastal plains; riverine and estuarine systems with accompanying deltas or floodplains; foothills of adjacent coastal ranges; coastal and mountain range escarpments, some with exposed summits and peaks; elevated 
Fig. 16.1 Forests of East Australia Hotspot. Follows the boundaries of two WWF Ecoregions: the Queensland Tropical Rain forests in the north and the Eastern Australian Temperate Forests in the south

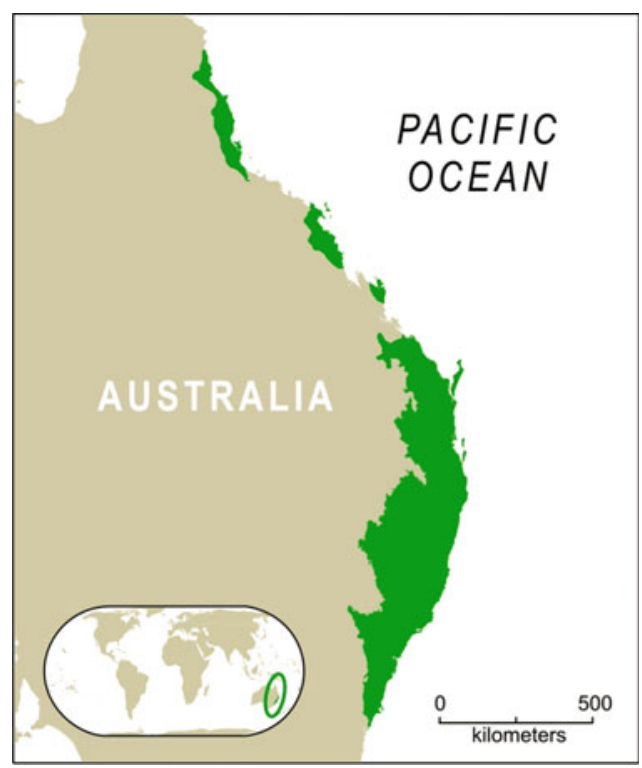

tablelands; undulating drier inland slopes and plains, particularly in north-west New South Wales; and naturally occurring freshwater lagoons and lakes.

The dominant rock types include Mesozoic sandstones and acid igneous rocks, with relatively recent basalts in the north. Varied soils result in a mosaic pattern of vegetation, with infertile soils throughout much of the hotspot, except for localized basalt-derived soils which are thinly spread throughout the latitudinal range of the hotspot. Sclerophyllous communities dominated by Australia's iconic plant, the gum-tree (Eucalyptus species), are the most prevalent vegetation type. Significant areas of rain forest exist throughout the region, much of which has existed continuously since Gondwanan times, providing a rich living record of evolution during well over 100 million years. In higher rainfall area on more fertile soils, forest trees can reach $70 \mathrm{~m}$ high. In both lower rainfall and subalpine areas, grasses and herbs become more dominant within grassy woodlands with eucalypts only 8-15 m high.

\subsection{Methods}

\subsubsection{Plant Diversity and Endemism}

Vascular plant records were compiled from the Australian National Herbarium (2005) and Queensland Herbarium (2003). Nomenclature follows Henderson (Henderson 2002) where applicable, or otherwise Stevens (2001 onward). A taxon was determined to be endemic to the hotspot if it was known from more than ten records and completely within the region of interest, or $>50$ records and 
95\% within the region. Taxa were defined as probably endemic if known from $<10$ records, completely within the region of interest or $<50$ records and $88 \%$ within the region. Some taxa were defined as requiring further assessment where there were less than five records with $>70 \%$ occurring within the region. Formal and popular literature were used to validate the status of some species, including The Flora of New South Wales (Harden 1990-1993), the Queensland Census (Henderson 2002), Fairley and Moore (1989) from the Sydney Region, The Native Vegetation of New South Wales (Keith 2004), Fruits of the Rainforest (Cooper 2004), Rainforest Trees of Southeast Australia (Floyd 1989), Flora of Australia (Pteridophytes) (ABRS/ CSIRO Australia 1998), and Eucalypts (Brooker and Kleinig 1994). Taxa with manuscript names were not considered. Taxa that satisfied the above criteria were then further scrutinized with the use of the above-mentioned literature. Such an approach reduced the effect of inaccurate locality information and geocodes.

\subsubsection{Vertebrate Diversity and Endemism}

For birds and reptiles, we used data compiled in the Australian Natural Heritage Assessment Tool (ANHAT) current to August 2006 (Department of Environment and Heritage 2006). Vertebrate taxonomy was based on the Australian Faunal Directory (ABRS 2006). To allow for varying levels of spatial precision, distribution records were summarized to a grid of $10 \times 10 \mathrm{~km}$ cells covering the hotspot. Records collected before 1950 or with a potential spatial error $>20 \mathrm{~km}$ were excluded from the analysis (see Slatyer et al. 2007) for more details on data preparation for an Australia-wide endemism analysis). Species with $<3$ records within the hotspot were assumed to be erroneous or vagrant and excluded from the hotspot species list, unless these records were the only ones for the species. In the latter case, further checks were performed to confirm the species endemism within the region. Allowing for a small percentage of erroneous records, species were found to be endemic to the hotspot if known from $\geq 50$ records with $\geq 95 \%$ of these records occurring within the hotspot or if known from 10-50 records with $100 \%$ of these within the hotspot. Species with $<10$ records or that just missed inclusion based on the above thresholds were subject to manual checking. Species found to be endemic were verified using published distribution information.

For consistency with other regions, the numbers for mammals and amphibians presented here are from a larger reanalysis for all hotspots based on the most recent IUCN Global Mammal Assessment and Global Amphibian Assessment (see chapter 1, Mittermeier et al., 2011). However, we also obtained results for mammals and amphibians using the methods described above for birds and reptiles. This more precise analysis yielded similar results to the IUCN Red List analysis. Both analyses yielded much higher estimates of total numbers of species and percent endemism than data obtained through WWF WildFinder (WWF 2006). 


\subsubsection{Primary Vegetation Extent}

The extent of primary vegetation is a criterion, along with the number of endemic vascular plants, in classifying a region as a global high biodiversity hotspot (Myers et al. 2000). We consider primary vegetation to be relatively pristine natural areas in which the majority of species and ecological processes are intact. Spatial analysis of amount and percent of primary vegetation remaining in the hotspot was based on data classified as "residual" by the Vegetation Assets, States and Transitions (VAST) framework (Fig. 16.2, Table 16.1). The VAST framework orders vegetation by degree of anthropogenic modification as a series of condition states, from a residual or baseline condition through to total removal (Thackway and Lesslie 2006; Thackway and Lesslie 2008). The residual classification corresponds well with the definition of primary vegetation.

\subsubsection{Land Use}

Spatial analysis of amount and percent of land use classes in the hotspot (Table 16.3) was based on the catchment-scale land use mapping for Australia (Bureau of Rural Sciences 2009) which applies the Australian Land Use and Management Classification (ACLUMP 2006).

\subsubsection{Area Protected}

Spatial analysis of amount and percent of hotspot area under formal protection (Table 16.4) was based on the Collaborative Australian Protected Areas Database current to 2006 (Department of the Environment Water Heritage and the Arts 2009).

\subsection{Unique Biodiversity}

A number of prehistoric events were responsible for the high levels of diversity and endemism found in the Forests of East Australia Hotspot. Geographic isolation of this region over millions of years resulted in sclerophyllous flora evolving from ancestral rain forest stock on nutrient-depleted soils, and desertification of central Australia promoted further speciation. Speciation within rain forest flora occurred in Gondwanan elements, gymnosperms, and basal lineage angiosperms. Subsequently, floral and vertebrate migrations occurred from the Indonesian plate, increasing with lowered sea level during periods of glaciation. Although many higher order taxa from the region have been catalogued, much of the biodiversity of the hotpot, as for the rest of Australia, remains unknown to science. 
a

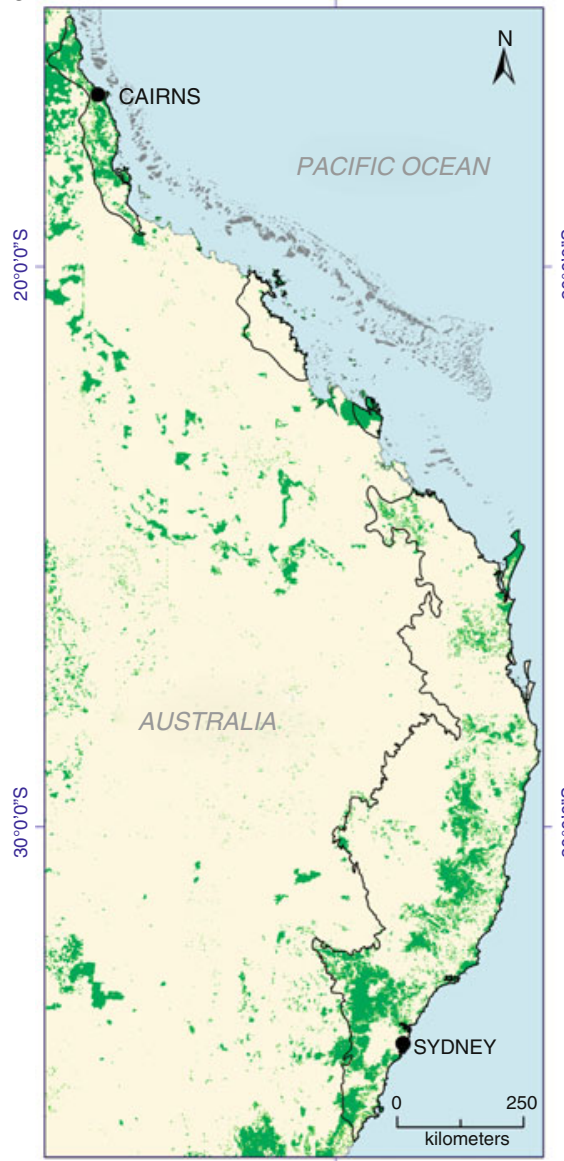

$150^{\circ} 0^{\prime} 0^{\prime \prime} \mathrm{E}$

\section{Legend}

Conservation

Natural environments

Production from relatively natural environments

Production from dryland agriculture and plantations

Production from irrigated agriculture and plantations Intensive uses

Water b

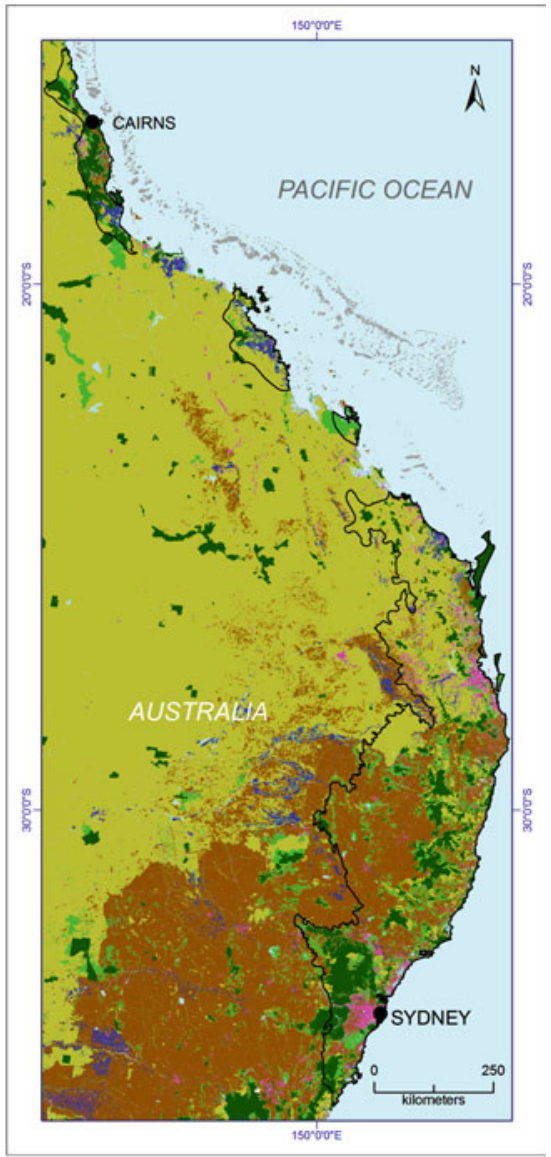

Fig. 16.2 (a) Extent of primary vegetation in the Forests of East Australia Hotspot (source: Thackway and Lesslie 2008). (b) Landuse in the Forests of East Australia Hotspot (source: Bureau of Rural Sciences 2009)

\subsubsection{Plants}

The hotspot consists of both rain forest and sclerophyllous communities with the sclerophyllous vegetation being dominant. Of 8,257 species of vascular plants, at 
Table 16.1 State of native vegetation in the Forests of East Australia Hotspot (after Lesslie et al. 2008; Thackway and Lesslie 2006; Thackway and Lesslie 2008). Primary forest remaining in the hotspot is defined as the residual and naturally bare class

\begin{tabular}{|c|c|c|c|}
\hline Category & Vegetation State & $\begin{array}{l}\text { Area } \\
\left(\mathrm{km}^{2}\right)\end{array}$ & $\begin{array}{l}\text { Percent } \\
\text { of total }\end{array}$ \\
\hline $\begin{array}{l}\text { Residual and } \\
\text { naturally } \\
\text { bare }\end{array}$ & $\begin{array}{l}\text { Native vegetation structure, composition, and } \\
\text { regenerative capacity intact, including areas that are } \\
\text { naturally bare or naturally disturbed; not significantly } \\
\text { perturbed by land use / land management practice }\end{array}$ & 58,900 & 23.3 \\
\hline Modified & $\begin{array}{l}\text { Native vegetation community structure, composition, } \\
\text { and regenerative capacity intact, but perturbed by } \\
\text { land use/ and management practice }\end{array}$ & 65,300 & 25.8 \\
\hline & $\begin{array}{l}\text { Native vegetation community structure, composition, } \\
\text { and regenerative capacity significantly altered by }\end{array}$ & & \\
\hline Transformed & land use/land management practice & 6000 & 2.4 \\
\hline Replaced- & & & \\
\hline Managed & Native vegetation replaced with cultivated vegetation & 120,300 & 47.5 \\
\hline $\begin{array}{l}\text { Removed } \\
\text { Total }\end{array}$ & $\begin{array}{l}\text { Vegetation removed - alienation to nonvegetated land } \\
\text { cover }\end{array}$ & $\begin{array}{r}2,600 \\
253,200\end{array}$ & $\begin{array}{l}1.1 \\
100\end{array}$ \\
\hline
\end{tabular}

Table 16.2 Species diversity and endemism recorded for the Forests of East Australia Hotspot

\begin{tabular}{lrrrrl}
\hline Taxonomic Group & Species & $\begin{array}{c}\text { Endemic } \\
\text { species }\end{array}$ & $\begin{array}{l}\text { Percent } \\
\text { endemism }\end{array}$ & $\begin{array}{l}\text { Endemic } \\
\text { genera }^{c}\end{array}$ & $\begin{array}{l}\text { Endemic } \\
\text { families }\end{array}$ \\
\hline Plants - Flowering (dicots) & 5,884 & 1,731 & 29.4 & 73 & 1 \\
Plants - Flowering (monocots) & 1,917 & 294 & 15.3 & 22 & 2 \\
Plants - Gymnosperms & 71 & 35 & 49.3 & 2 & 0 \\
Plants - Ferns and allies & 385 & 84 & 21.8 & 2 & 0 \\
Vascular Plants - total & $>8,257$ & $>2,144$ & 25.9 & 99 & 3 \\
Birds & 549 & 28 & 5.1 & 3 & 0 \\
Mammals & 133 & $6^{\mathrm{a}}$ & 4.5 & 0 & 0 \\
Amphibians & 120 & $38^{\mathrm{a}}$ & 31.7 & $4^{\mathrm{b}}$ & 0 \\
Reptiles & 259 & 70 & 27.0 & 14 & 0 \\
Freshwater Fish & $>80$ & $>10$ & 12.5 & $>?$ & $>?$ \\
Vertebrates - total & $>1,141$ & $>152$ & 13.3 & $>21$ & $>?$ \\
\hline
\end{tabular}

${ }^{a}$ The analysis described in Sect. 16.2.2 yielded higher total numbers of endemic species for mammals (12) and amphibians (43) than shown. While these higher numbers are likely more accurate, we used the IUCN analysis here for consistency with other regions

${ }^{\mathrm{b}}$ One amphibian genus included in this count, Rheobatrachus, is probably extinct, giving 3 extant amphibian genera

${ }^{\mathrm{c}}$ Endemic genera listed in Appendix 1 by family

least 2,144 are endemic (26\%); exceeding the 1,500 endemic species required for a biodiversity hotspot (Table 16.2). Surprisingly, only 99 of 2,031 genera (5\%) are endemic, but a further 26 genera may include some endemics following further review of their status. Of particular note is the fact that three families occur nowhere else in the world (Doryanthaceae and the monotypic Austrobaileyaceae and Petermanniaceae). This is a very high level of plant endemism at the family level, 
and places this hotspot second or third among all hotspots in this category. One member of the Doryanthaceae family, the Giant or Gymea Lily (Doryanthes excelsa), has edible roots and flower spikes, traditionally eaten roasted by Aboriginal people (see Fig. 16.3). Basal angiosperms are a conspicuous component of the rain forest flora, with both Austrobaileya (see Fig. 16.3) and Trimenia (Trimeniaceae) being members of the ANITA grade of magnoliids.

The hotspot is also home to the recently discovered and Critically Endangered Wollemi Pine (Wollemia nobilis), which has fewer than 50 mature individuals. It is considered a living fossil, with all other members of its genus extinct for over 2 million years. This species is restricted to the Wollemi National Park, within the Blue Mountains World Heritage Area (Fig. 16.3).

The hotspot harbors 32 globally threatened plant species according to the 2009 IUCN Red List (IUCN 2009): one Critically Endangered, 12 Endangered, and 19 Vulnerable. It also contains $27 \%$ of the 1,296 plant species considered rare or threatened in Australia by the Environmental Protection and Biodiversity Conservation Act 1999 (the EPBC Act).

\subsubsection{Vertebrates}

Overall vertebrate endemism is about $13 \%$, including information for amphibians, reptiles, birds, mammals, and freshwater fish. Of vertebrate species in the hotspot, amphibian species endemism is the highest (32\%; Table 16.2). However, there have been several amphibian extinctions in the recent past, with the extinction of the two remarkable species of gastric-brooding frog being the most noteworthy. More hopeful is the story of the Yellow-Spotted Bellfrog (Litoria castanea, CR). The species had not been sighted since 1980, and was thought to have declined mainly due to chytridiomycosis. Widely thought to be extinct, the species was recorded in 2008 and a population of about 100 was confirmed in 2009. Possible resistance to chytridiomycosis of remaining individuals is being studied.

Reptile endemism is also high (27\%; Table 16.2). One endemic reptile, the rain forest-dwelling Boyd's Forest Dragon (Hypsilurus boydii), is unusual in that its body temperature is generally within one degree of air temperature (see Fig. 16.3).

A total of 28 out of 549 birds (5\%) are considered endemic (Table 16.2). The extraordinary colorful Paradise Parrot (Psephotus pulcherrimus) was likely endemic to the hotspot, but is considered extinct, with the last sighting in 1927. The species fed mainly on grass seeds and nested in hollowed termite mounds. The cause of extinction is unknown, but contributing factors may have included trapping and egg collection, disease, predation by introduced mammals, changes to the fire regime, and reduction of food supply due to overgrazing and land clearing.

We estimate that well over 80 freshwater fish species are present in the hotspot, of which over 10 (or approximately 13\%) are endemic (Unmack 2001; Wet Tropics Management Authority 2010; Table 16.2). These numbers are almost certainly underestimates, and further analysis of freshwater fish data using finer-scale basin 


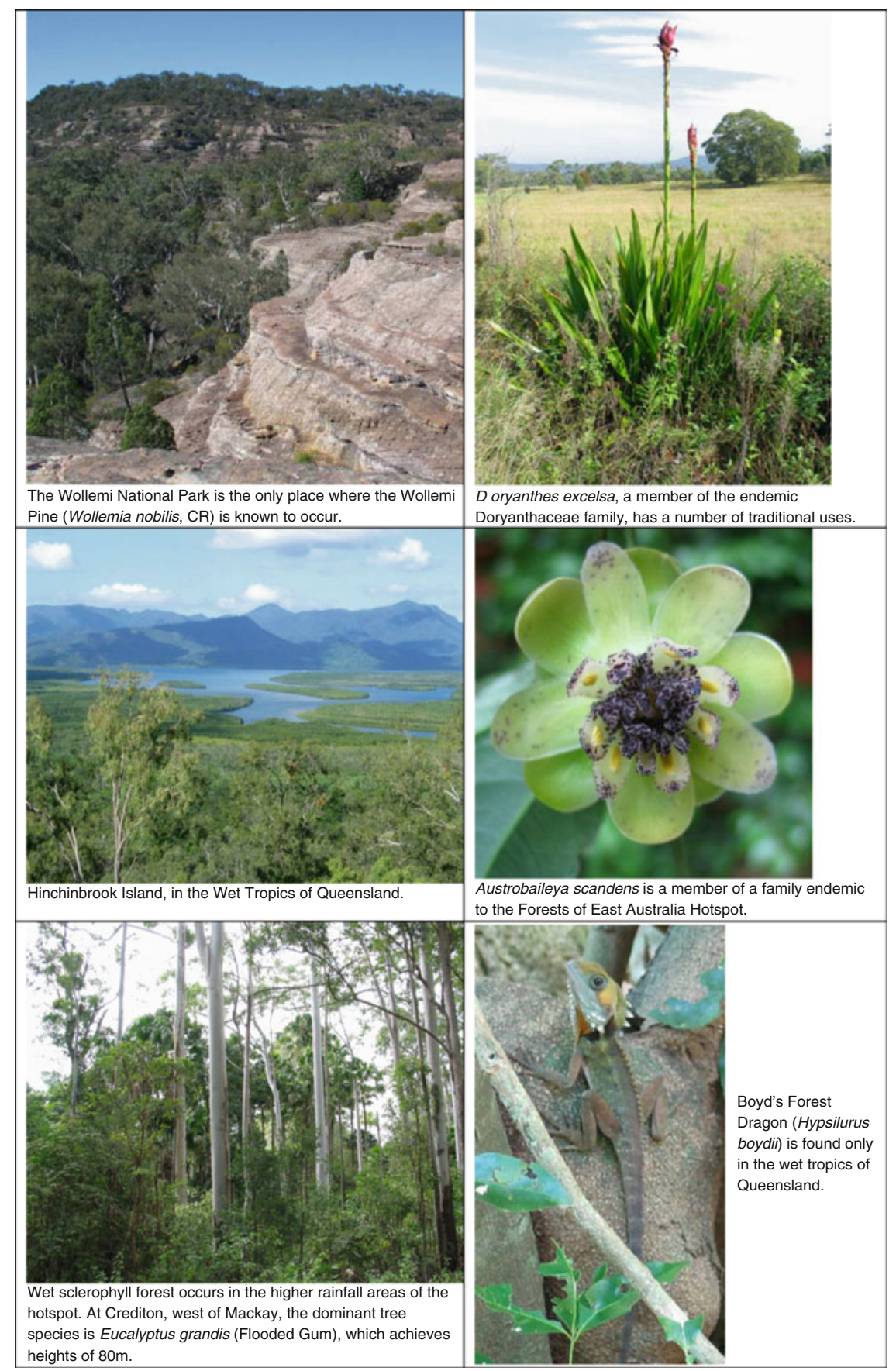

Fig. 16.3 Example landscapes, flora and fauna in the Forests of East Australia Hotspot 
Table 16.3 Primary land use types in the Forests of East Australia Hotspot (ACLUMP 2006, Bureau of Rural Sciences 2009)

\begin{tabular}{lcc}
\hline Land uses & Area $\left(\mathrm{km}^{2)}\right.$ & Percent of total \\
\hline Conservation and natural environments & 82,200 & 32.5 \\
Intensive land use (urban and agricultural) & 13,700 & 5.4 \\
Production from dryland agriculture and plantations & 70,400 & 27.8 \\
Production from irrigated agriculture and plantations & 5,700 & 2.3 \\
Production from relatively natural environments & 75,600 & 29.9 \\
Water & 5,600 & 2.2 \\
Total & 253,200 & 100 \\
\hline
\end{tabular}

Table 16.4 IUCN categories of protection in the Forests of East Australia Hotspot (Department of the Environment Water Heritage and the Arts 2009)

\begin{tabular}{lcc}
\hline IUCN category & Area $\left(\mathrm{km}^{2}\right)$ & $\begin{array}{r}\text { Percent } \\
\text { of total }\end{array}$ \\
\hline I: Strict Nature Reserve & 15,800 & 6.24 \\
II: National Parks & 25,200 & 9.96 \\
III: Natural Monument & 200 & 0.09 \\
IV: Habitat/species Management Area & 100 & 0.04 \\
V: Protected Landscape & 100 & 0.04 \\
VI: Managed Resource Protected Area & 5,200 & 2.04 \\
Total & 46,600 & 18.40 \\
\hline
\end{tabular}

data is needed to generate a more accurate estimate of diversity and endemism within the hotspot boundaries.

\subsection{Human Impact}

The human population of the hotspot as of 2006 was 9,147,190, with a population density of 36 people per square kilometer (see Mittermeier et al. 2011) for details on this analysis, which utilized LandScan ${ }^{\text {TM }}$ GP2007 data (ORNL 2007). Much of the population is concentrated along the coast.

Approximately $58,900 \mathrm{~km}^{2}(23 \%)$ of the hotspot comprises primary vegetation (Table 16.1). This analysis used data compiled between 1995 and 2003 (Thackway and Lesslie 2008) to determine that more than $70 \%$ of the total land area of the hotspot has lost its primary vegetation. More than $65 \%$ of the hotspot is under some form of production land use (Fig. 16.3, Table 16.3).

In the north of the hotspot, within the Queensland Tropical Rain Forests Ecoregion, major threats include invasive pest species and habitat fragmentation, although substantial areas are now protected in the Wet Tropics World Heritage Area. Fragmentation within forest patches through road and powerline construction also increases the spread of invasive species and facilitates the entry of fire. Phytophthora cinnamomi, a highly invasive, soil-borne water mold, has resulted in significant rain forest dieback at some sites. Pollution from agricultural runoff is 
an additional threat. The Ecoregion itself is listed by WWF as "Vulnerable" (Olson and Dinerstein 2002).

Human impact is even higher further south, within the Eastern Australian Temperate Forests Ecoregion, listed by WWF as "Critical/Endangered" (Olson and Dinerstein 2002). Population density is higher in this part of the hotspot, and major threats are related to ongoing clearing of native vegetation for urban development, introduced species, altered fire regimes, water pollution, and schemes for water use.

Threats within protected areas throughout the hotspot include tourism, altered fire regimes, sewage disposal, and invasive plants and animals. Specific threats to amphibians include chytridiomycosis, which is suggested as a cause for a number of recent species extinctions and was first detected as a major threat to amphibian species in Queensland in the 1990s.

\subsection{Conservation Actions}

A combined total of about $46,600 \mathrm{~km}^{2}(18 \%)$ of the land area in the Forests of East Australia Hotspot is under some form of formal protection, with a total of $41,300 \mathrm{~km}^{2}$ (16\%) falling within IUCN protected area categories I-IV (Table 16.4). The Royal National Park, south of Sydney, was the second proclaimed National Park in the world. Fraser Island, the Blue Mountains, the Gondwana Rain Forests, and the Wet Tropics of Queensland are all UNESCO World Heritage Areas (e.g., Hinchinbrook Island, see Fig. 16.3) and the Noosa region is a UNESCO Biosphere Reserve. Gaps in the protected area network include some centers of plant endemism and some areas of critical habitat for threatened species.

Recent reductions in rabbit populations in the tablelands of New South Wales and other areas and the introduction of voluntary habitat protection schemes on farms have led to the recovery of some native vegetation. The cessation of broadscale clearing in Queensland at the end of 2006 will lead to a further reduction in the rate of loss of native vegetation, though the condition of remnants in production landscapes has continued to decline (Wilson et al. 2008). Biodiversity has become increasingly vulnerable because of loss of habitat extent and reduced ecosystem resilience, possibly aggravated by enhanced climatic variability (Beeton et al. 2006). Community-based landscape restoration programs, such as the Great Eastern Ranges initiative (NSW Australian 2010) and environmental stewardships (Government 2010; Wilson et al. 2008) are increasingly important mechanisms, assisting land managers to protect the natural environment.

Acknowledgments We are grateful for the use of data or assistance provided by the following institutions and individuals: CSIRO Sustainable Ecosystems, Atherton and Canberra; the Queensland Herbarium, Department of Environment and Resource Management, Brisbane; Australian National Herbarium, CSIRO Centre for Plant Biodiversity Research, Canberra; John Benson and Doug Benson, Botanic Gardens Trust, Sydney; Daniel P. Faith and The Australian Museum, Sydney; David Keith and Department of Conservation and Environment, Sydney; 
Cameron Slatyer and Department of the Environment, Water, Heritage and the Arts, Canberra; Trevor Parker; Richard Thackway and Bureau of Rural Sciences, Canberra; National Land and Water Resources Audit, Canberra; Queensland Museum, Brisbane; CSIRO Australian National Wildlife Collection, Canberra; Birds Australia; NSW Department of Environment and Climate Change; NSW Department of Primary Industry, Forests NSW; Geosciences Australia; World Wildlife Fund; Kellee Koenig, Ian Harrison, and Conservation International; IUCN; Department of Natural Resources, Mines and Energy, Queensland; Land and Property Information, New South Wales; Museum and Art Gallery of the Northern Territory; Museum Victoria; South Australian Museum; Western Australian Museum; Commonwealth Department of Defence; Northern Territory Department of Natural Resources, Environment and the Arts; WildNet, Queensland Environmental Protection Agency, Brisbane; South Australian Department for Environment and Heritage; Tasmanian Department of Primary Industries and Water; Victorian Department of Sustainability and Environment. Support also was provided by the "2010 Working Group" within the Australian Research Council, Environmental Futures Network (see Williams et al. 2006). Photographs in Fig. 16.3 by A.F., CSIRO.

\section{Appendix 1: List of Genus-level Endemic Vertebrate Animals (Excluding Freshwater Fish) and Vascular Plants Known from the Forests of East Australia Hotspot}

\begin{tabular}{lll}
\hline Vertebrate group & Family & Genus \\
\hline Birds & Acanthizidae & Oreoscopus \\
Birds & Acanthizidae & Origma \\
Birds & Ptilonorhynchidae & Scenopoeetes \\
Amphibians & Myobatrachidae & Taudactylus \\
Amphibians & Myobatrachidae & Rheobatrachus* \\
Amphibians & Myobatrachidae & Assa \\
Amphibians & Myobatrachidae & Adelotus \\
Reptiles & Elapidae & Tropidechis \\
Reptiles & Elapidae & Cacophis \\
Reptiles & Gekkonidae & Phyllurus \\
Reptiles & Gekkonidae & Carphodactylus \\
Reptiles & Scincidae & Calyptotis \\
Reptiles & Scincidae & Gnypetoscincus \\
Reptiles & Scincidae & Ophioscincus \\
Reptiles & Scincidae & Harrisoniascincus \\
Reptiles & Scincidae & Coeranoscincus \\
Reptiles & Scincidae & Eroticoscincus \\
Reptiles & Scincidae & Saiphos \\
Reptiles & Scincidae & Coggeria \\
Reptiles & Scincidae & Nangura \\
Reptiles & Chelidae & Elusor \\
\hline
\end{tabular}




\begin{tabular}{|c|c|c|}
\hline Vascular plant group & Family & Genus \\
\hline Flowering (dicots) & Akaniaceae & Akania \\
\hline Flowering (dicots) & Alseuosmiaceae & Crispiloba \\
\hline Flowering (dicots) & Anacardiaceae & Rhodosphaera \\
\hline Flowering (dicots) & Araliaceae & Cephalaralia \\
\hline Flowering (dicots) & Araliaceae & Motherwellia \\
\hline Flowering (dicots) & Austrobaileyaceae & Austrobaileya \\
\hline Flowering (dicots) & Celastraceae & Hedraianthera \\
\hline Flowering (dicots) & Celastraceae & Hexaspora \\
\hline Flowering (dicots) & Celastraceae & Hypsophila \\
\hline Flowering (dicots) & Cunoniaceae & Acrophyllum \\
\hline Flowering (dicots) & Cunoniaceae & Davidsonia \\
\hline Flowering (dicots) & Cunoniaceae & Pseudoweinmannia \\
\hline Flowering (dicots) & Cunoniaceae & Vesselowskya \\
\hline Flowering (dicots) & Elaeocarpaceae & Peripentadenia \\
\hline Flowering (dicots) & Ericaceae & Rupicola \\
\hline Flowering (dicots) & Euphorbiaceae & Hylandia \\
\hline Flowering (dicots) & Euphorbiaceae & Rockinghamia \\
\hline Flowering (dicots) & Fabaceae & Almaleea \\
\hline Flowering (dicots) & Flacourtiaceae & Baileyoxylon \\
\hline Flowering (dicots) & Flacourtiaceae & Streptothamnus \\
\hline Flowering (dicots) & Gesneriaceae & Lenbrassia \\
\hline Flowering (dicots) & Grossulariaceae & Cuttsia \\
\hline Flowering (dicots) & Hamamelidaceae & Neostrearia \\
\hline Flowering (dicots) & Hamamelidaceae & Noahdendron \\
\hline Flowering (dicots) & Hamamelidaceae & Ostrearia \\
\hline Flowering (dicots) & Icacinaceae & Irvingbaileya \\
\hline Flowering (dicots) & Loranthaceae & Atkinsonia \\
\hline Flowering (dicots) & Loranthaceae & Benthamina \\
\hline Flowering (dicots) & Meliaceae & Synoum \\
\hline Flowering (dicots) & Menispermaceae & Echinostephia \\
\hline Flowering (dicots) & Monimiaceae & Austromatthaea \\
\hline Flowering (dicots) & Monimiaceae & Endressia \\
\hline Flowering (dicots) & Monimiaceae & Hemmantia \\
\hline Flowering (dicots) & Myrtaceae & Anetholea \\
\hline Flowering (dicots) & Myrtaceae & Austromyrtus \\
\hline Flowering (dicots) & Myrtaceae & Barongia \\
\hline Flowering (dicots) & Myrtaceae & Choricarpia \\
\hline Flowering (dicots) & Myrtaceae & Lenwebbia \\
\hline Flowering (dicots) & Myrtaceae & Mitrantia \\
\hline Flowering (dicots) & Myrtaceae & Ristantia \\
\hline Flowering (dicots) & Myrtaceae & Sphaerantia \\
\hline Flowering (dicots) & Myrtaceae & Stockwellia \\
\hline Flowering (dicots) & Myrtaceae & Tristania \\
\hline Flowering (dicots) & Myrtaceae & Waterhousea \\
\hline Flowering (dicots) & Proteaceae & Athertonia \\
\hline Flowering (dicots) & Proteaceae & Austromuellera \\
\hline Flowering (dicots) & Proteaceae & Buckinghamia \\
\hline Flowering (dicots) & Proteaceae & Cardwellia \\
\hline
\end{tabular}




\begin{tabular}{|c|c|c|}
\hline Vascular plant group & Family & Genus \\
\hline Flowering (dicots) & Proteaceae & Carnarvonia \\
\hline Flowering (dicots) & Proteaceae & Catalepidia \\
\hline Flowering (dicots) & Proteaceae & Darlingia \\
\hline Flowering (dicots) & Proteaceae & Eidothea \\
\hline Flowering (dicots) & Proteaceae & Floydia \\
\hline Flowering (dicots) & Proteaceae & Hicksbeachia \\
\hline Flowering (dicots) & Proteaceae & Hollandaea \\
\hline Flowering (dicots) & Proteaceae & Megahertzia \\
\hline Flowering (dicots) & Proteaceae & Musgravea \\
\hline Flowering (dicots) & Proteaceae & Neorites \\
\hline Flowering (dicots) & Proteaceae & Opisthiolepis \\
\hline Flowering (dicots) & Proteaceae & Placospermum \\
\hline Flowering (dicots) & Proteaceae & Sphalmium \\
\hline Flowering (dicots) & Proteaceae & Triunia \\
\hline Flowering (dicots) & Rhamnaceae & Schistocarpaea \\
\hline Flowering (dicots) & Rubiaceae & Durringtonia \\
\hline Flowering (dicots) & Rutaceae & Brombya \\
\hline Flowering (dicots) & Rutaceae & Pentaceras \\
\hline Flowering (dicots) & Sapindaceae & Castanospora \\
\hline Flowering (dicots) & Sapindaceae & Sarcotoechia \\
\hline Flowering (dicots) & Sterculiaceae & Franciscodendron \\
\hline Flowering (dicots) & Surianaceae & Guilfoylia \\
\hline Flowering (monocots) & Anthericaceae & Alania \\
\hline Flowering (monocots) & Arecaceae & Laccospadix \\
\hline Flowering (monocots) & Arecaceae & Normanbya \\
\hline Flowering (monocots) & Arecaceae & Oraniopsis \\
\hline Flowering (monocots) & Asteliaceae & Neoastelia \\
\hline Flowering (monocots) & Convallariaceae & Kuntheria \\
\hline Flowering (monocots) & Convallariaceae & Tripladenia \\
\hline Flowering (monocots) & Cyperaceae & Ptilothrix \\
\hline Flowering (monocots) & Doryanthaceae & Doryanthes \\
\hline Flowering (monocots) & Juncaginaceae & Maundia \\
\hline Flowering (monocots) & Orchidaceae & Cooktownia \\
\hline Flowering (monocots) & Orchidaceae & Corunastylis \\
\hline Flowering (monocots) & Orchidaceae & Corymborkis \\
\hline Flowering (monocots) & Orchidaceae & Papillilabium \\
\hline Flowering (monocots) & Orchidaceae & Peristeranthus \\
\hline Flowering (monocots) & Orchidaceae & Rimacola \\
\hline Flowering (monocots) & Orchidaceae & Schistotylus \\
\hline Flowering (monocots) & Petermanniaceae & Petermannia \\
\hline Flowering (monocots) & Poaceae & Alexfloydia \\
\hline Flowering (monocots) & Poaceae & Notochloe \\
\hline Flowering (monocots) & Poaceae & Potamophila \\
\hline Flowering (monocots) & Restionaceae & Coleocarya \\
\hline Gymnosperms & Araucariaceae & Wollemia \\
\hline Gymnosperms & Zamiaceae & Lepidozamia \\
\hline Ferns and allies & Blechnaceae & Pteridoblechnum \\
\hline Ferns and allies & Dryopteridaceae & Revwattsia \\
\hline
\end{tabular}

*Probably extinct 


\section{References}

ABRS (2006) Australian Faunal Directory: http://www.environment.gov.au/biodiversity/abrs/ online-resources/fauna/afd/index.html, Access Date: 2006. Australian Biological Resources Study, Canberra

ABRS/CSIRO Australia (1998) Flora of Australia Volume 48: Ferns, gymnosperms and allied groups. CSIRO, Melbourne, Victoria

ACLUMP (2006) Guidelines for land use mapping in Australia: principles, procedures and definitions: a technical handbook supporting the Australian Collaborative Land Use Mapping Programme Edition 3. Bureau of Rural Sciences, Australian Government, Canberra

Australian Government (2010) Caring for our country - environmental stewardship, website accessed 2nd July 2010: http://www.nrm.gov.au/stewardship/index.html. Australian Government, Canberra

Australian National Herbarium (CANB) (2005) Australian National Herbarium Specimen Information Register (ANHSIR) database [on-line, ASCII text]. Access Date: Jan 2005. Australian National Herbarium, Canberra

Beeton RJS, Buckley KI, Jones GJ, Morgan D, Reichelt RE, Trewin D (2006) Chapter 5 Biodiversity, Australia State of the Environment 2006: http://www.environment.gov.au/soe/ 2006/publications/report/biodiversity.html 2006 Australian State of Environment Committee, Canberra

Brooker MIH, Kleinig DA (1994) Field guide to Eucalypts volume 3. Inkata, Port Melbourne

Bureau of Rural Sciences (2009) Metadata: catchment scale land use mapping for Australia update May 2009 (CLUM Update 05/09) dataset. Department of Agriculture, Fisheries and Forestry, Australian Government, Canberra

Cooper W (2004) Fruits of the Australian Tropical Rainforest. Nokomis Editions, Melbourne

Department of Environment and Heritage (2006) Australian National Heritage Assessment Tool (ANHAT) [digital dataset]. Access Date: August 2006. Australian Government, Canberra

Department of the Environment Water Heritage and the Arts (2009) Collaborative Australian Protected Areas Database - CAPAD 2006 (digital spatial data). Department of the Environment, Water, Heritage and the Arts, Australian Government, Canberra

Fairley A, Moore P (1989) Native plants of the Sydney district: an identification guide. Kangaroo Press in association with Society for Growing Australian Plants, Kenthurst, NSW

Floyd AG (1989) Rainforest trees of Mainland South-eastern Australia. Inkata, Lismore, NSW

Harden GJ (1990-1993) Flora of New South Wales, (volumes 1-4). New South Wales University Press, Sydney

Henderson RJF (2002) Names and distribution of Queensland plants, Algae and Lichens. Environmental Protection Agency, Queensland Government, Brisbane

IUCN (2009) 2009 IUCN Red list of threatened species. Accessed online: February 2010. http:// www.iucnredlist.org. International Union for Conservation of Nature, Gland

Keith DA (2004) Ocean shores to desert dunes: the native vegetation of New South Wales and the ACT. Department of Environment and Conservation, New South Wales National Parks and Wildlife Service, Sydney

Lesslie L, Thackway R, Smith J (2008) A national-level Vegetation Assets, States and Transitions (VAST) dataset for Australia, version 2.0 [Digital Data]. Bureau of Rural Sciences, Australian Government, Canberra

Mittermeier RA, Robles Gil P, Hoffmann M, Pilgrim J, Brooks T, Goettsch Mittermeier C, Lamoreux J, Da Fonseca GAB (2004) Hotspots revisited: earth's biologically richest and most endangered terrestrial ecoregions. CEMEX, Agrupación Sierra Madre, SC

Mittermeier RA, Turner WR, Larsen FW, Brooks TM, Gascon C (2011) Global biodiversity conservation: the critical role of hotspots. In: Zachos FE, Habel JC (eds) Biodiversity hotspots: distribution and protection of conservation priority areas. Springer, Heidelberg

Myers N (1988) Threatened Biotas: "Hot Spots" in Tropical Forests. The Environmentalist 8:187-208 
Myers N, Mittermeier RA, Mittermeier CG, da Fonseca GAB, Kent J (2000) Biodiversity hotspots for conservation priorities. Nature 403:853-858

NSW Government (2010) The Great Eastern Ranges, connecting people....connecting nature, a continental scale conservation vision for Australia, website accessed 2nd July 2010: http:// www.greateasternranges.org.au/. NSW Government, Sydney

Olson DM, Dinerstein E (2002) The Global 200: Priority ecoregions for global conservation. Ann Mo Bot Gard 89:199-224

ORNL (2007) Population Density 2007, Available at http://www.ornl.gov/landscan/. UT-Battelle, LLC, operator of Oak Ridge National Laboratory, Oak Ridge

Queensland Herbarium (BRI) (2003) Herbarium Records System (HERBRECS) database [digital dataset]. Access Date: 2003. Environmental Protection Agency, Brisbane

Slatyer C, Rosauer D, Lemckert F (2007) An assessment of endemism and species richness patterns in the Australian Anura. J Biogeogr 34:583-596

Stanton JP, Bostock PD, McDonald KR, Werren GL, Fleming A (2004) Queensland wet tropics. In: Mittermeier RA, Robles Gil P, Hoffmann M, Pilgrim J, Brooks T, Goettsch Mittermeier C, Lamoreux J, Da Fonseca GAB (eds) Hotspots revisited: Earth's biologically richest and most endangered terrestrial ecoregions. CEMEX, S.A. de C.V., Agrupación Sierra Madre, S.C.

Stevens PF (2001 onwards) Angiosperm Phylogeny Website: http://www.mobot.org/MOBOT/ research/APweb/. Version 9, June 2008 [and more or less continuously updated since]. Missouri Botanical Garden and University of Missouri, St Louis

Thackway R, Lesslie R (2006) Reporting vegetation condition using the Vegetation Assets, States and Transitions (VAST) framework. Ecol Manage Restor 7:S53-S62

Thackway R, Lesslie R (2008) Describing and mapping human-induced vegetation change in the Australian landscape. Environ Manage 42:572-590

Unmack PJ (2001) Biogeography of Australian freshwater fishes. J Biogeogr 28:1053-1089

Wet Tropics Management Authority (2010) Freshwater fish - General information, http://www. wettropics.gov.au/pa/pa_fish_info.html, accessed March 2010. Queensland Government, Cairns

Williams KJ, Faith DP, Ford A, Metcalfe D, Pert P, Rosauer D, Slatyer C, Ferrier S, Cogger H, Margules C, James R (2006) Progress in defining the status and extent of a global highbiodiversity hotpot in Eastern Australia. In: Gole C (eds) Abstracts of the Conservation Planning Symposium, 27-29 September 2006. WWF Australia and the Southwest Australia Ecoregion Initiative, Perth Convention Centre, Western Australia, pp 11-12

Wilson B, Young P, Niehus R (2008) Habitat protection. In: Freeman J, Webber W (eds) State of the environment Queensland 2007. Environmental Protection Agency, Queensland Government, Brisbane

WWF (2006) WildFinder: www.worldwildlife.org/WildFinder, Online database of species distributions, version Jan 2006, accessed January 2010. World Wildlife Fund, Washington, DC, USA 